\title{
Assesment of Lipid Profile Status in Hypothyroid Patients Attending Tertiary Care Center
}

\author{
Renuka $\mathrm{P}^{1^{*}}$, Umamaheshwari $\mathrm{V}^{2}$, Subarathi ${ }^{3}$ Deepa $\mathrm{P}^{4}$
}

${ }^{1,3}$ Assistant Professor in Govt. Stanley Medical College, No. 1, Old Jail Rd, George Town, Chennai, Tamil Nadu 600001, India

${ }^{2}$ Associate Professor in Govt. Omandurar Medical College, 169, Wallajah Road, Police Quarters, Triplicane, Chennai, Tamil Nadu 600002, India

${ }^{4}$ Assistant Professor in Stanley Medical College Chennai, Tamil Nadu, India

DOI: $10.36347 /$ sjams.2020.v08i10.026

| Received: 04.10.2020 | Accepted: 19.10.2020 | Published: 23.10.2020

*Corresponding author: Renuka $\mathrm{P}$

Abstract

Original Research Article

One of the major complication of hypothyroidism is atherosclerosis and cardio vascular disease. In worldwide, atherosclerosis is one of the leading cause of death and disability. Thyroid hormone increases LPL enzyme activity, LDL receptor gene expression, HMG CoA reductase activity and increases cholesterol excretion. In hypothyroidism hypercholesterolemia leads to production of reactive oxygen species that oxidises LDL which favours formation of atheromatous plaque which is responsible for foam cell formation [1]. Treatment with thyroxine decreases cholesterol level by upregulation of LDL receptors and increases its excretion through bile. This study group included 30 recently diagnosed hypothyroid individuals, 30 treated hypothyroid patients and 30 apparently healthy controls with age and sex matched. Thyroid profile and Lipid profile were measured in fasting blood samples. Total cholesterol, triglycerides and LDL-cholesterol were increased in recently diagnosed hypothyroidism compared to treated hypothyroidism and controls with the $\mathrm{p}$ value of $<0.001$. By this study we confirmed that altered lipid profile in hypothyroidism, one of the treatable cause for atherosclerosis. During treatment with thyroxine, hypothyroid patients should monitored for lipid profile, which may used as screening test to identify cardiovascular risk.

Keywords: Hypothyroidism, dyslipidemia \& hypothyroidism, lipid profile.

Copyright $\odot 2020$ The Author(s): This is an open-access article distributed under the terms of the Creative Commons Attribution 4.0 International License (CC BY-NC 4.0) which permits unrestricted use, distribution, and reproduction in any medium for non-commercial use provided the original author and source are credited.

\section{INTRODUCTION}

Thyroid diseases are common worldwide. In India too, thyroid diseases are more prevalent. Thyroid disorders are the most common among all the endocrine diseases [2]. In India $11 \%$ of the population are affected from hypothyroidism. Women were three times more prone for hypothyroidism than men [3]. Almost 1 in every 10 person are affected with hypothyroidism. Overt hypothyroidism has been found to be associated with cardiovascular disease.

Lipids are transported in the plasma as lipoproteins. There are four major classes of lipids carried by lipoproteins - cholesteryl ester (36\%), phospholipids (30\%), triacylglycerols (16\%), cholesterol (14\%) and much less fraction of free fatty acids.

Effects of Thyroid hormone on Fat metabolism:

- Thyroid hormone increases lipolysis

- Stimulates Fatty acid oxidation

- Lowers plasma cholesterol and triglycerides level
Lipid profile in Hypothyroidism

- Thyroid hormone enhances adipose tissue metabolism and increases production of adipokines.

- Thyroid hormone stimulates hydroxymethylglutaryl CoA [HMG CoA] reductase the rate limiting step in cholesterol synthesis and increases intracellular cholesterol concentration [4].

- It increases lipoprotein lipase activity which metabolises triglyceride containing lipoproteins VLDL, IDL and Chylomicrons into fattyacids and glycerol.

- It affects HDL metabolism by stimulating cholesteryl ester transfer protein which exchanges cholesteryl ester from HDL2 to VLDL, IDL and triglycerides in the opposite direction. Also it increases hepatic lipase activity which metabolizes HDL2 to HDL3 [5, $6,8]$.

- Thyroid hormone increases LDL receptor gene expression by stimulating promoter region of LDL receptor gene which contains thyroid 
response element and regulates LDL receptor at mRNA level [7].

- In hypothyroidism, LDL cholesterol levels are increased and oxidised [9, 10]

Effects of altered Lipid profile on Hypothyroidism

- In hypothyroidism hypercholesterolemia leads to production of reactive oxygen species that oxidises LDL. This damages endothelial cells and decreases nitric oxide production and favours formation of atheromatous plaque which is responsible for foam cell formation [10].

\section{Materials ANd Methods}

Case - control study was conducted after obtaining institutional ethical committee clearance.

Group 1: 30 newly diagnosed hypothyroid individuals of age around 15-45 years

Group 2: 30 hypothyroid patients between > 3 months to $<1$ year duration of treatment.

Group 3: 30 controls with age and gender matched

Exclusion criteria for both cases and controls:

1. Chronic smokers

2. Pregnancy \& lactation
3. Diabetes mellitus

4. Renal disease

5. Liver disease

6. Megaloblastic anemia by peripheral smear and

7. Patients on other medication for a long time were excluded.

Fasting venous blood samples are collected at EDTA test tube with strict aseptic precautions. Thyroid profile- Total T3 and T4 were measured by competitive ELISA and TSH by non competitive ELISA.

Total Cholesterol was Estimated by Cholesterol Esterase-Oxidase- Peroxidase Method, Triglycerides by Glycerol phosphate oxidase method, HDL Cholesterol by Direct method and LDL cholesterol calculated by Friedwald's formula.

A statistical analysis was done by ANOVA and Post HOC test to compare Fasting lipid profile and TSH levels between three groups. Correlation of TSH with lipid profile parameters was done by using Pearson Correlation Coefficient.

Table-1: Characteristics of Controls, Treated Hypothyroidism and Recently Diagnosed Hypothyroidism

\begin{tabular}{|c|c|c|c|c|c|}
\hline \multicolumn{2}{|c|}{ PARAMETERS } & CONTROLS & $\begin{array}{l}\text { TREATED } \\
\text { HYPOTHYROIDISM }\end{array}$ & $\begin{array}{l}\text { RECENTLY DIAGNOSED } \\
\text { HYPOTHYROIDISM }\end{array}$ & P VALUE \\
\hline \multicolumn{2}{|l|}{ AGE } & $28.57 \pm 5.85$ & $29.27 \pm 6.3$ & $30.57 \pm 7.26$ & $\begin{array}{l}0.496 \\
\text { NS }\end{array}$ \\
\hline \multirow[t]{2}{*}{ SEX } & MALE & $4[13.3 \%]$ & $1[3.3 \%]$ & $4[13.3 \%]$ & \\
\hline & FEMALE & $26[86.7 \%]$ & $29[96.7 \%]$ & $26[86.7 \%]$ & \\
\hline \multicolumn{2}{|c|}{ BODY MASS INDEX } & $21.14 \pm 1.53$ & $26.64 \pm 5.04$ & $26.8 \pm 5.9$ & $<0.001 * *$ \\
\hline \multicolumn{2}{|c|}{ TSH $[\mu \mathrm{IU} / \mathrm{L}]$} & $2.26 \pm 1.07$ & $2.26 \pm 1.3$ & $45.4 \pm 51.02$ & $<0.001 * *$ \\
\hline \multicolumn{2}{|c|}{ TOTAL CHOLESTEROL [mg/dl] } & $142.7 \pm 23.62$ & $159.6 \pm 19.83$ & $170.9 \pm 35.5$ & $<0.001 * *$ \\
\hline \multicolumn{2}{|c|}{ TRIGLYCERIDES [mg/dl] } & $92.7 \pm 31.27$ & $145.77 \pm 57.32$ & $159.2 \pm 74.98$ & $<0.001 * *$ \\
\hline \multicolumn{2}{|c|}{ LDL-c [mg/dl] } & $66.26 \pm 21.57$ & $74.31 \pm 17.94$ & $76.99 \pm 30.5$ & $<0.001 * *$ \\
\hline \multicolumn{2}{|c|}{$\mathrm{HDL}-\mathrm{c}[\mathrm{mg} / \mathrm{dl}]$} & $57.9 \pm 7.45$ & $56.13 \pm 6.14$ & $62.1 \pm 14.52$ & 0.068 \\
\hline
\end{tabular}

NS - Non significant; * - significant; ** Highly significant

Table-1 shows baseline characteristics and biochemical parameters of the controls, treated hypothyroidism and recently diagnosed hypothyroidism cases.

No significant difference were found in the distribution of age and sex among the study groups. This shows that the study is age and sex matched.
Highly significant difference was observed between the study groups in Body mass index, total cholesterol, triglycerides, LDL-cholesterol, TSH with the $\mathrm{p}$ value $<0.001$.

There is no significant difference in HDLcholesterol between the study groups.

Table-2: Comparison of Characteristics between Recently Diagnosed Hypothyroidism and Treated Hypothyroidism
\begin{tabular}{|l|l|l|l|}
\hline PARAMETERS & $\begin{array}{l}\text { RECENTLY DIAGNOSED } \\
\text { HYPOTHYROIDISM }\end{array}$ & $\begin{array}{l}\text { TREATED } \\
\text { HYPOTHYROIDISM }\end{array}$ & P VALUE \\
\hline BODY MASS INDEX & $26.8 \pm 5.9$ & $26.64 \pm 5.04$ & $0.919 \mathrm{NS}$ \\
\hline TSH $[\mu \mathrm{IU} / \mathrm{L}]$ & $45.4 \pm 51.02$ & $2.26 \pm 1.3$ & $<0.001 * *$ \\
\hline TOTAL CHOLESTEROL[mg/dl] & $170.9 \pm 35.5$ & $159.6 \pm 19.83$ & $0.005 *$ \\
\hline TRIGLYCERIDES $[\mathrm{mg} / \mathrm{dl}]$ & $159.2 \pm 74.98$ & $145.77 \pm 57.32$ & $0.366 \mathrm{NS}$ \\
\hline LDL-c $[\mathrm{mg} / \mathrm{dl}]$ & $76.99 \pm 30.5$ & $74.31 \pm 17.94$ & $0.085 \mathrm{NS}$ \\
\hline HDL $-\mathrm{c}[\mathrm{mg} / \mathrm{dl}]$ & $62.1 \pm 14.52$ & $56.13 \pm 6.14$ & $0.024 *$ \\
\hline
\end{tabular}

NS - Non significant $\quad$ *- Significant $\quad * *$ - Highly significant 
- Table-2 shows comparison of characteristics between recently diagnosed hypothyroidism and treated hypothyroidism.

- Among these two study groups Total cholesterol, HDL-cholesterol and TSH levels were significant.

- Triglycerides, LDL-cholesterol and Body mass index were found to be not statistically significant between these two study groups.

\section{Conclusion}

- Lipid profile was significantly altered in recently diagnosed hypothyroidism. The parameters like total cholesterol, TGL, LDL cholesterol and HDL were in higher range as compared to controls and treated hypothyroidism.

- Early diagnosis and treatment of hypothyroidism plays a major role in preventing the metabolic abnormality and several complications like infertility, birth defects, cardiovascular disease etc.

- During treatment with thyroxine, hypothyroid patients should be monitored for lipid profile.

\section{LIMITATION}

LDL cholesterol was not measured, calculated.

\section{REFERENCES}

1. Li D, Saldeen T, Mehta JL. Effects of $\alpha$ tocopherol on ox-LDL-mediated degradation of
NF- $\mathrm{KB}$ and apoptosis in cultured human coronary artery endothelial cells. Journal of Cardiovascular Pharmacology, 2000; 36(3):297-301.

2. Kochupillai N. Clinical Endocrinology in India. 2 Current Science. 2000; 8:1061-7.

3. Unnikrishnan AG. Abott india presents new data on hypothyroidism. Indian Journal of Endocrinology and Metabolism. July 2013.

4. Ness GC, Dugan RE, Lakshmanan MR, Nepokroeff CM, Porter JW. Stimulation of hepatic TM-hydroxy-methyl-glutaryl Coenzyme A reductase in hypophysectomized rats by $\mathrm{L}$ triiodothyronine. Proc Natl Acad Sci USA. 1973; 70:3839-3842.

5. Jiskra J, Limanova Z, Antosova M. Thyroid diseases, dyslipidemia and cardiovascular risk: vnitr Lek. 2007 Apr; 53(4):382-5.

6. Duntas LH. Thyroid disease and Lipids: Thyroid. 2002 Apr; 12(4):287-93.

7. Bakker O, Hudig F, Meijssen S, Wiersinga WM. Effects of triiodothyronine and amiodarone on the promoter of the human LDL receptor gene. Biochem Biophys Res Commun. 1998; 240:517521.

8. Rizos CV, Elisaf MS, Liberopoulos EN. Effects of Thyroid Dysfunction on Lipid Profile : The open cardiovascular Medicine Journal. 2011; 5:76-84.

9. Evagelos NL, Moses SE. Dyslipidemia in patients with Thyroid disorders: Hormones. 2002; 1(4):218-223.

10. Liberopoulos EN, Elisaf MS. Dyslipidemia in patients with thyroid disorders. Hormones. 2002; 1:218-23. 